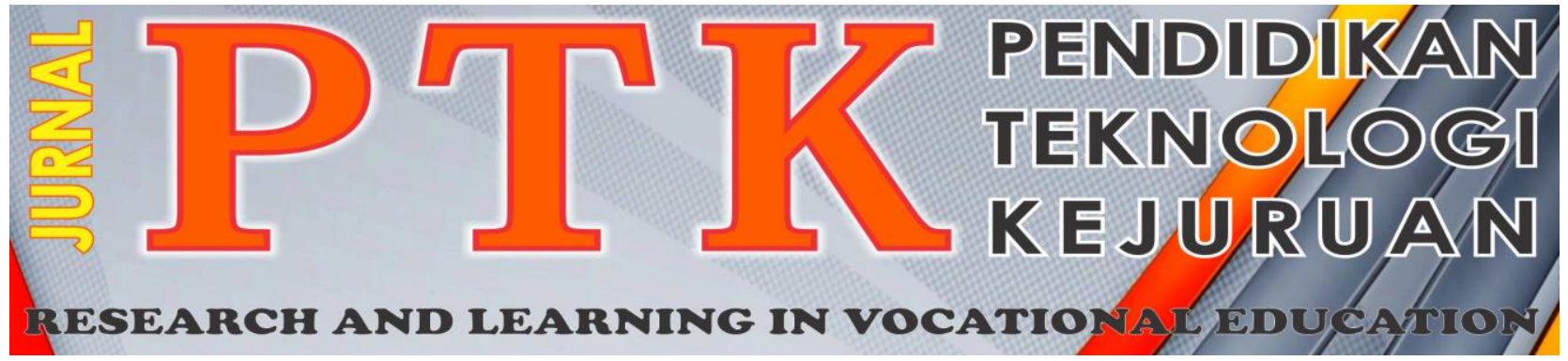

Vol. 1, No. 2 Mei 2018

P-ISSN: 2621-3273

E-ISSN: 2621-1548

\title{
PENGEMBANGAN MODUL DAN TRAINER MENGGUNAKAN MOTOR DC BERBASIS ATMEGA 16 PADA PEMBELAJARAN INSTALASI MOTOR LISTRIK
}

\author{
Purwanto $^{1 *}$ Ganefrii $^{2}$ dan Nurhasan Syah ${ }^{3}$ \\ ${ }^{1}$ Jurusan Teknik Elektro, SMK Sinar Husni 2 TR Labuhan Deli \\ ${ }^{23}$ Program Studi Pendidikan Teknologi dan Kejuruan, Universitas Negeri Padang \\ *Corresponding author, e-mail: drs.purwanto63@gmail.com ${ }^{1}$
}

\begin{abstract}
Abstrak - Artikel ini bertujuan mengembangkan Modul dan Trainer menggunakan Motor DC berbasis Atmega 16 untuk mendukung Pembelajaran Praktek Instalasi Motor Listrik. Rancangan pengembangan media pembelajaran ini dilakukan melalui tahapan pengembangan dan prosedur atau langkah yang dipersiapkan terlebih dahulu, yaitu: (1) melakukan analisis produk yang akan dikembangkan, (2) mengembangkan produk awal, (3) Validasi ahli materi dan ahli media dan revisi, (4) uji coba lapangan skala kecil, (5) uji coba lapangan skala besar. Tahapan yang diambil dimaksudkan untuk memperoleh media pembelajaran yang sesuai dengan kebutuhan peserta didik. Kesimpulan yang dapat diperoleh dari penelitian ini adalah : Pengembangkan Modul dan Trainer Menggunakan Motor DC Berbasis Atmega 16 pada Pembelajaran Instalasi Motor Listrik, secara signifikan berhasil meningkatkan efektifitas dan efisiensi pembelajaran praktek. Hal ini dibuktikan dengan melihat nilai rata-rata hasil belajar kelas yang tidak menggunakan media Modul dan Trainer 6,16 sedangkan nilai rata rata kelas yang menggunakan media Modul dan Trainer 7,94..
\end{abstract}

Kata kunci : pengembangan, media pembelajaran modul dan trainer, pembelajaran praktek instalasi motor listrik

Abstract- this article aims to develop Module and Trainer using Electric Motors DC based Atmega 16 to support Installing Electric Motors practical learning. The development design of instructional media is carried out the development stage through procedures or steps that are prepared in advance, namely: (1) Analyzing the product to be developed, (2) Developing initial product, (3) Validation from the experts, (4) Field testing in a small-scale, (5) Field testing in a large-scale. The stages are taken for the purpose of obtaining media that suit the needs of the learners. The conclusion that can be derived from this study are researchers succeeded in developing Module and Trainer Using Electric Motors DC motors Based Atmega 16, to support Installing Electric Motors practical learning significantly improve the effectiveness and efficiency of practical learning. This is evidenced by looking at the average value of the class not using the media Module and Trainer 6,16 and the average value of a class that use the Media and Trainer 7.94.

Keywords: Development, modul and trainer learning media, instructional practice, electric motors installation

Copyright (C) 2018 JPTK. All rights reserved

\section{Pendahuluan}

SMK Sinar Husni 2 TR Labuhan Deli, Kabupaten Deli Serdang, Propinsi Sumatera Utara merupakan salah satu SMK kelompok Teknologi, dengan Bidang Keahlian: Teknologi dan Rekayasa. Saat ini SMK Sinar Husni 2 TR Labuhan Deli, memiliki tiga Paket Keahlian, yaitu: Teknik Instalasi Pemanfaatan Tenaga Listrik, Teknik Sepeda Motor, dan Teknik Kendaraan Ringan. Sebagai wahana pendidikan SMK Sinar Husni 2 TR Labuhan Deli melaksanakan proses interaksi pembelajaran antara peserta didik dengan guru dan sumber belajar. Untuk mendapatkan hasil yang maksimal maka, proses pembelajaran perlu direncanakan, dilaksanakan, dinilai, dan diawasi agar terlaksana secara efektif dan efisien. 
Materi pelajaran Instalasi Motor yang dimuat di Kurikulum 2013, menghendaki adanya pelaksanaan Praktek menggunakan Elektronika Daya. Sebagai contoh pada KD 4.4: Menentukan Pemasangan Instalasi Kontrol Motor non PLC berbasis Elektronika, dengan Materi Pokok Pembelajaran: Pemasangan Komponen Elektronika Daya non PLC untuk mengontrol Instalasi Motor Motor Listrik. Terjadi kesenjangan antara harapan yang di tuntut oleh perusahaan-perusahaan pengguna tamatan dengan pelaksanaan pembelajaran praktek di sekolah. Berdasarkan hasil observasi awal pada pelajaran praktek pemasangan Instalasi Motor Listrik kelas XI di SMK Sinar Husni 2 TR Labuhan Deli, dalam penyampaian materi pembelajaran praktek cendrung bersifat konvensional yang berpusat pada guru (teacher centre) yang kurang memotivasi siswa untuk belajar. Kemudian belum tersedia peralatan praktek pengontrolan motor motor listrik berbasis elektronika daya seperti tuntutan kurikulum.

Untuk meningkatkan hasil belajar, banyak faktor yang perlu disiapkan dan diperbaiki terutama yang berhubungan dengan pembelajaran Instalasi Motor Listrik. Hasil pengamatan awal menunjukkan sebagian besar siswa SMK Sinar Husni 2 TR Labuhan Deli Program Keahlian Teknik Instalasi Tenaga Listrik mengalami kesulitan dalam mempelajari konsep-konsep Elektronika Daya pada mata pelajaran Instalasi Motor Listrik. Penggunaan istilah teknologi Elektronika Daya yang belum familiar membuat siswa mengalami kesulitan saat mencoba memahami konsep dan cara kerja peralatan. Keterbatasan guru dalam mendesain dan mengelola serta menerapkan strategi pembelajaran ekspositori dan penggunaan media pembelajaran juga membuat siswa kurang tertarik dan kurang termotivasi dalam mempelajari Instalasi Motor Listrik [1].

Untuk memperbaiki fenomena tersebut komponen yang berhubungan dengan pembelajaran, perlu perbaikan secara khusus secara terus menerus demi kesempurnaan sehingga diminati oleh siswa dalam pembelajaran. Salah satu hal yang menentukan keberhasilan siswa dalam meraih prestasi adalah minat untuk belajar. Tentu tidak mudah dan perlu mendapat perhatian, agar minat belajar siswa terpancing dan megar dalam belajar. Salah satu upaya yang dapat diterapkan adalah pembelajaran dengan menggunakan modul dan trainer. Dengan menggunakan modul dan trainer penyajian akan lebih menarik. Modul dapat berupa lay out dan teks book, sedangkan trainer berupa pengadaan peralatan praktek untuk simulasi pekerjaan-pekerjaan teknik yang terjadi dilapangan. Dengan demikian akan lebih mudah dalam penerapan konsep konsep tentang Instalasi Motor Listrik yang mengacu kepada materi Elektronika Daya, dan dapat meningkatkan minat dan motivasi yang pada akhirnya akan meningkatkan hasil belajar siswa.Pembelajaran menggunakan modul dan trainer merupakan pendekatan pembelajaran mandiri yang berfokuskan penguasaan kompetensi dari bahan kajian yang dipelajari peserta didik dengan waktu tertentu sesuai dengan potensi dan kondisinya.

Modul adalah satu kesatuan program yang dapat mengukur tujuan. Modul dapat dipandang sebagai paket program yang disusun dalam bentuk satuan tertentu guna keperluan belajar. Pada kenyataannya modul merupakan jenis kegiatan belajar yang terencana, dirancang untuk membantu siswa secara individu maupun kelompok dalam mencapai tujuan belajar [2]. Pembelajaran dengan modul merupakan pendekatan pembelajaran mandiri yang berfokuskan penguasaan kompetensi dari bahan kajian yang dipelajari peserta didik atau siswa dengan waktu tertentu sesuai dengan potensi dan kondisinya. Pembelajaran menggunakan modul merupakan cara pengorganisasian material dan aktifitas dengan memahami tujuan khusus yang akan dicapai, memiliki opsi aktifitas yang dapat dipilih (seperti: observasi, diskusi, serta membaca teks). Pembelajaran dengan sistem modul bertujuan membuka kesempatan bagi peserta didik untuk belajar memahami materi dengan caranya masing pembelajaran menyediakan berbagai kegiatan pembelajaran seperti membaca materi ajar, mendengarkan dan demonstrasi praktikum[3].

Modul yang baik harus disusun secara sistematis, menarik, dan jelas. Modul dapat digunakan kapanpun dan dimanapun sesuai dengan kebutuhan siswa. Karakteristik modul pembelajaran sebagai berikut :

1. Self instructional, Siswa mampu membelajarkan diri sendiri, tidak tergantung pada pihak lain.

2. Self contained, Seluruh materi pembelajaran dari satu unit kompetensi yang dipelajari terdapat didalam satu modul utuh.

3. Stand alone, Modul yang dikembangkan tidak tergantung pada media lain atau tidak harus digunakan bersama-sama dengan media lain.

4. Adaptif, Modul hendaknya memiliki daya adaptif yang tinggi terhadap perkembangan ilmu dan teknologi.

5. User friendly, Modul hendaknya juga memenuhi kaidah akrab bersahabat/akrab dengan pemakainya.

6. Konsistensi, Konsisten dalam penggunaan font, spasi, dan tata letak. 
Berdasarkan beberapa pendapat di atas maka dapat disimpulkan bahwa dalam pembelajaran menggunakan modul juga memiliki beberapa kelemahan yang mendasar yaitu bahwa memerlukan biaya yang cukup besar serta memerlukan waktu yang lama dalam pengadaan atau pengembangan modul itu sendiri, dan membutuhkan ketekunan tinggi dari guru sebagai fasilitator untuk terus memantau proses belajar siswa.

Selain penggunaan modul pembelajaran, seorang guru juga harus memperhatikan kecerdasan/inteligensi siswa. Keberhasilan belajar tergantung pada bagaimana siswa mengelola kemampuan berpikir logis, menguasai/mengetahui perilaku, berkomunikasi cakap serta menerima hubungan secara kompleks didalam belajar, sehingga apa yang dikerjakan dalam belajar selalu berdasarkan intelektual yang terkendali. Kecerdasan/ kemampuan sangat penting dalam proses pembelajaran karena kemampuan anak dapat membaca situasi, menarik dan mendorong perhatian serta dapat mengendalikan kondisi dalam diri seseorang. Oleh karena itu kecerdasan dan pembelajaran dengan menggunakan media dan modul perlu diperhatikan agar hasil belajar yang diharapkan dapat tercapai secara optimal

Tujuan dari Penelitian Pengembangan ini adalah untuk menghasilkan Modul dan Trainer menggunakan Motor DC berbasis Atmega 16 yang valid, praktis dan efektif pada pembelajaran Instalasi Motor Listrik, yang dapat mendukung kebutuhan belajar siswa dalam meningkatkan hasil belajar sesuai dengan silabus dan RPP Kompetensi Dasar Instalasi Motor ListrikKelas XI Program Keahlian Teknik Instalasi Tenaga Listrik.

\section{METODE}

Penelitian ini akan mengembangkan sebuah modul pembelajaran simulasi menggunakan MediaTrainer Motor DC berbasis Micro Controler Atmega 16 pada Mata Pelajaran Instalasi Motor Listrik.[4] Model pembelajaran Trainer bertujuan untuk mengembangkan pemahamansiswa terhadap materi yang disampaikan, sehingga siswa dapat menguasai setiap kompetensi yang diinginkan dengan baik. Meningkatnya kompetensi siswa merupakan indikator perwujudan dari hasil pembelajaran yang dilaksanakan guru telah berjalan dengan baik. Dengan menggunakan simulator Trainer Sistem Kendali Motor DC berbasis MC Atmega 16 pada mata pelajaran Instalasi Motor Listrik, diharapkan siswa dapat lebih leluasa mencobakan berbagai program pada alat-alat tiruan yang mendekati alat-alat aslinya dan dapat meningkatkan kompetensi pembelajaran yang harus dikuasai. Dengan demikian siswa tamatan kelak uptodate dengan perkembangan teknologi dan kebutuhan teknisi di lapangan.[5]

Subyek uji coba untuk penelitian pengembangan ini adalah 32 orang siswa kelas XI L 2 sebagai kelas Eksperiman, dan 32 orang siswa kelas XI L 3, sebagai kelas kontrol. Kedua kelas tersebut berasal dari Paket Keahlian Teknik Instalasi Pemanfaatan Tenaga Listrik SMK Sinar Husni 2 TR Labuhan Deli, Kabupaten Deli Serdang, dengan Mata Pelajaran Instalasi Motor Listrik semester ganjil Juli-Desember 2015. Data penelitian didapat dari, Instrumen Validasi Modul, untuk Ahli Media, Instrumen Praktikalitas Modul untuk Siswa dan Guru, dan Instrumen Efektivitas dengan menggunakan kelas kontrol dan kelas eksperimen.

Prosedur pengembangan secara keseluruhan digambar seperti Gambar di bawah ini :

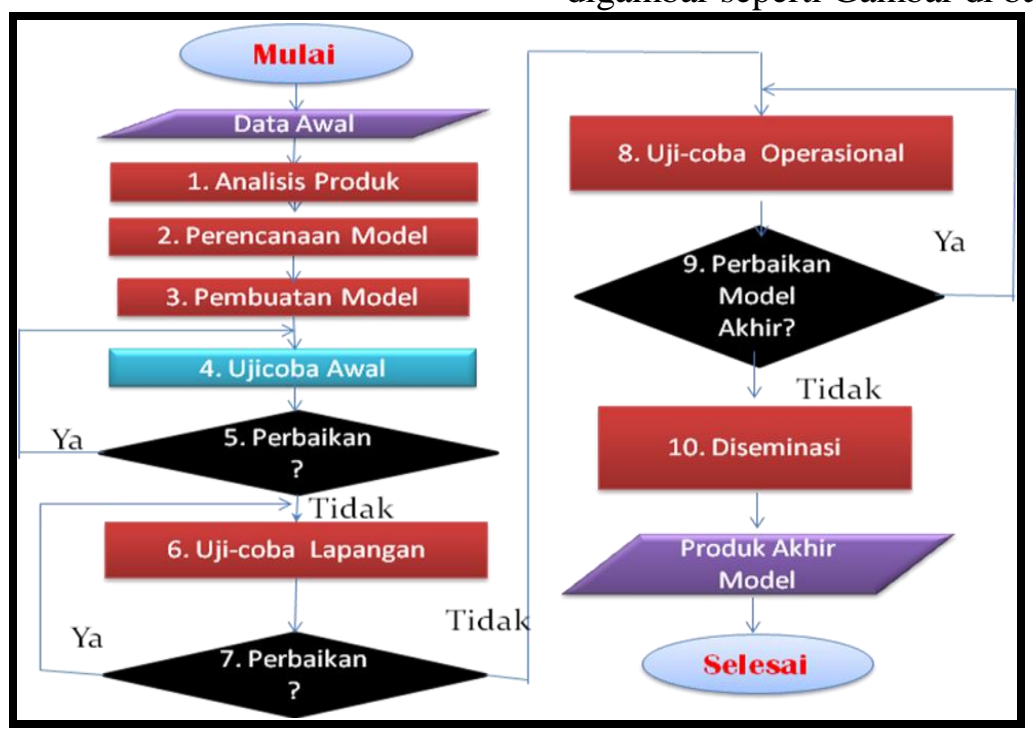

Gambar 1. Diagram Alur Pengembangan 
Instrument penelitian yang dikembangkan untuk mengumpulkan data dalam penelitian ini adalah observasi, wawancara, dan angket.Analisis data dilakukan atas data awal yang diperoleh dan atas data hasil validasi pengembangan produk awal oleh pakar (ahli). Teknik analisis data yang digunakan adalah deskriptif. Dengan teknik deskriptif ini maka peneliti akan mendiskripsikan atau menggambarkan data yang telah terkumpul sebagaimana adanya tanpa bermaksud untuk membuat kesimpulan yang berlaku untuk umum atau generalisasi[6]. Pada fase analisis kebutuhan modul maka peneliti akan menggambarkan kebutuhan materi yang harus ada pada modul Instalasi Motor Listrik di SMK Sinar Husni 2 TR labuhan Deli, khususnya Program Keahlian Teknik Instalasi Tenaga Listrik.

\section{SPESIFIKASI PRODUK}

Trainer menggunakan trainer Motor DC berbasis ATmega 16 yang akan digunakan pada pembelajaran Instalasi Motor Listrik ini, merupakan pengembangan dari Silabus KD 4.4 pada program keahlian Teknik Instalasi Tenaga Listrik, Bidang Keahlian Ketenagalistrikan, kurikulum Nasional 2015. Trainer ini berisikan sistem pengendali yang terprogram dengan menggunakan perangkat IC. Setelah menguasai teori pengoperasian Trainer ini peserta didik diharapkan memiliki pengetahuan, keterampilan, dan sikap bagaimana cara menggunakan Trainer Motor DC berbasis ATMega 16 dan mengaplikasikannya untuk mesin produksi yang menggunakan kendali elektronik daya.

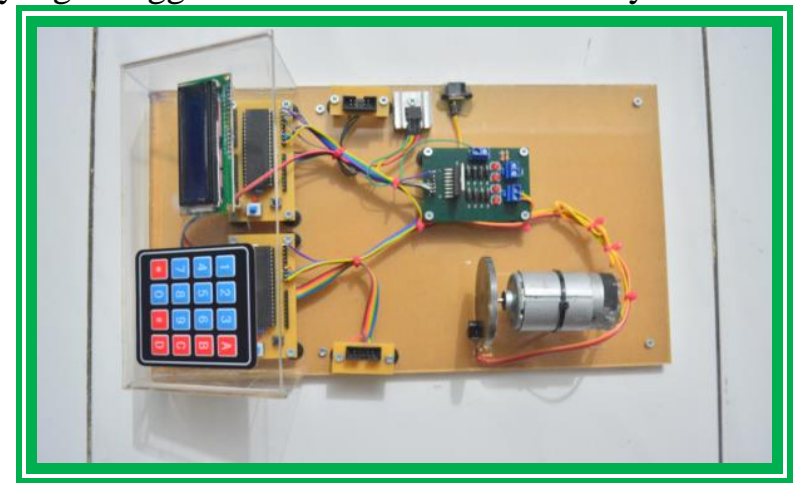

Gambar 2. Trainer Kendali Motor DC Berbasis Atmega 16

\section{Fungsi Komponen Trainer}

Secara sederhana Trainer Motor DC berbasis Atmega 16 memiliki enam komponen, hubungan keenam komponen tersebut digambarkan melalui blok diagram berikut :

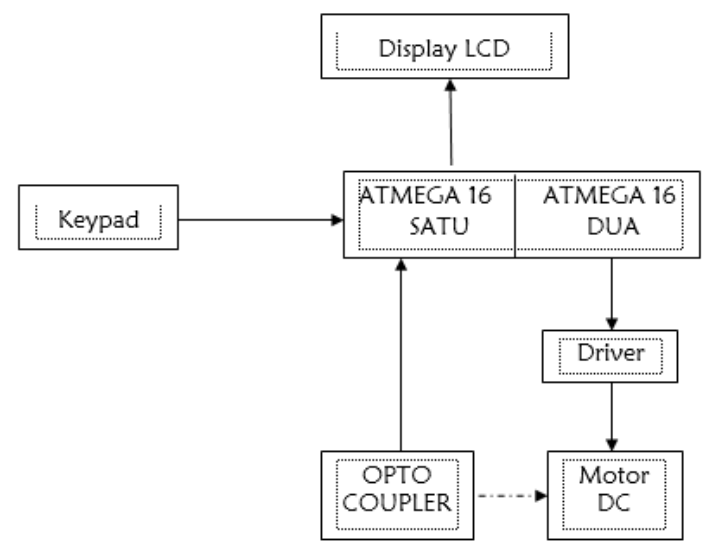

\section{Gambar 3. Blok Diagram Trainer Motor DC berbasis Atmega 16}

Adapun fungsi komponen berdasarkan blok diagram di atas adalah sebagai berikut :

a. Atmega 16 : Microcontroller, yang akan digunakan sebagai pusat pengolahan data. Pada Trainer ini terdapat 2 Buah Mikrokontroler Atmega 16, dengan fungsi yang berbeda. MC Atmega 16-1 berfungsi menerima dan mengolah data masuk, sedangkan MC Atmega 16-2 berfungsi sebagai penerima masukan umpan balik, yang datang dari optocoupler ke MC Atmega 16-1, dan melakukan perbaikan data sesuai perintah yang datang dari keypad.

b. Display LCD : Adalah merupakan tampilan informasi menggunakan LCD 16X2, Display ini akan menampilkan data yang sudah di program, dan akan di tampilkan sesuai perintah yang diberikan dari keypad.

c. Keypad : Sebagai input data, menggunakan keypad 4X4, berisi angka angka dan huruf untuk memberi kode dan bahasa pemrograman.

d. Driver IC L 298 : Sebagai penguat pengendali kecepatan motor, Seperti relay yang bertugas memperkuat arus untuk menggerakkan motor listrik DC sebagai beban.

e. Motor DC : Adalah sebuah motor yang digerakkan dengan sumber DC.

f. Optocoupler : Sebagai sensor penghitung kecepatan motor berputar, data yang diterima akan dilaporkan ke Microcontroler Atmega 16-2 untuk disesuaikan dan diperbaiki sesuai perintah.

\section{Urutan kerja Trainer Motor DC berbasis Atmega 16}

Urutan kerja Trainer Motor DC berbasis Atmega 16 adalah sebagai berikut :

a. Masukkan Pesan yang diinginkan kepada keypad.

b. Perhatikan display LCD, amati tampilan pesan yang diberikan oleh Keypad. 
c. Info dari Keypad yang ditampilkan di Display LCD, di teruskan ke Mikrokontroler Atmega 16 2.

d. Mikrokontroler Atmega 16 - 2 mengirim perintah ke Driver untuk menggerakkan Motor Listrik DC.

e. Driver Menggerakkan motor DC, sesuai perintah yang diberikan dari Mikrokontrol Atmega 16-2.

f. Motor DC bekerja, sesuai masukan yang datang dari Driver IC L 298.

g. Bersamaan dengan berputarnya Motor DC, Octocoupler mendeteksi kebenaran perintah yang datang dari Mikrokontroler Atmega 16 - 2, untuk dikoreksi kebenarannya oleh Mikrokontroler Atmega 16 - 1 .

h. Selanjutnya Mikrokontroler Atmega $16-1$ menampilkan info koreksi ke Display LCD, jika tidak sesuai, maka MC Atmega 16-1 akan mengirim data ke MC Atmega 16 - 2 dan diteruskan ke Driver guna menyesuaikan kecepatan sesuai pesanan perintah.

\section{Tiga Menu Operasional Trainer Motor DC berbasis Atmega 16}

Trainer ini memiliki 3 (tiga) model menu pengoperasian. Ketiganya berhubungan dengan pengaturan kecepatan putaran motor listrik DC, yaitu :

a. Menu A digunakan untuk menentukan arah putaran motor DC. Putaran Motor DC dapat dilakukan untuk arah kiri dan kanan. Perubahan polaritas sumber tegangan yang masuk ke motor DC akan merubah arah putaran motor itu sendiri. Perubahan polaritas ini ditandai dengan cahaya LED yang terdapat pada terminal masuk ke Motor DC. Aplikasi menu A ini digunakan untuk menaikkan atau menurunkan barang, atau menggeser barang ke kiri atau ke kanan.

b. Menu B digunakan untuk mempertahankan kecepatan putaran Motor DC yang sudah dipesan melalui keypad. Satuan putaran yang dibentuk dalam putaran motor ini masih dalam satuan detik, belum dalam satuan RPM, jadi untuk mejadi RPM harus dikalikan 60. Motor Listrik DC akan terus menerus berputar sesuai pesanan, sampai tombol off ditekan. Aplikasi menu B ini digunakan untuk putaran motor yang stabil dan terus menerus sejumlah putaran yang diinginkan, dan baru berhenti ketika tombol off ditekan. Misalnya putaran motor ban berjalan atau belt conveyor.

c. Menu C digunakan untuk memesan jumlah putaran Motor DC yang diinginkan melalui keypad. Setelah motor DC berputar sesuai pesanan yang dilakukan melalui Keypad, maka motor listrik DC akan berhenti, dengan sendirinya. Aplikasi menu $\mathrm{C}$ digunakan pada Haspel penggulung kabel listrik, atau penggulung gelondongan kain produksi tekstil.

\section{Pembahasan}

\section{Analisa Aspek Efisiensi Produk}

Nilai efisiensi diukur dengan cara observasi pelaksanaan praktek menggunakan Modul Instalasi Motor Listrik Menggunakan Trainer Motor DC Berbasis ATMega 16. Panduan pelaksanaan Praktek dilakukan menggunakan Pedoman Pelaksanaan Praktek. Aspek efensiensi dapat dilihat dari penghematan waktu setelah praktek Modul Instalasi Motor Listrik Menggunakan Trainer Motor DC Berbasis ATMega 16 dilaksanakan siswa. Hasil rekapitulasi menunjukkan ada percepatan sebesar 90 menit dari target waktu yang telah ditetapkan.

Berdasarkan post test siswa kelas kontrol yang tidak praktek Modul Instalasi Motor Listrik Menggunakan Trainer Motor DC Berbasis ATMega 16, diketahui belum mampu memenuhi target waktu penguasaan materi yang telah ditetapkan, sesuai alokasi waktu yang ada pada silabus .Sedangkan hasil postest siswa kelas Eksprimen yang praktek dengan materi yang sama yakni Modul Instalasi Motor Listrik Menggunakan Trainer Motor DC Berbasis ATMega 16, mampu memenuhi target alokasi waktu yang telah ditetapkan. Terlihat adanya perbedaan penghematan waktu yang sangat signifikan.

Pada pembelajaran praktek Modul Instalasi Motor Listrik Menggunakan Trainer Motor DC Berbasis ATMega 16, ternyata mampu meningkatkan hasil belajar siswa, yang secara langsung dapat mempengaruhi kualitas kinerja praktek Instalasi Motor Listrik, sehingga waktu pemahaman yang terpakai dalam praktik ini tidak terlalu lama. Pada kegiatan inti pembelajaran, bahan ajar membantu siswa untuk dapat menguasai hal-hal paling essensial dari kapabilitas yang telah ditetapkan didalam tujuan pembelajaran, yang diberikan melalui latihan.

Pada kegiatan akhir pembelajaran, pembelajaran dapat menjadi lebih effisien karena bahan ajar modul menyediakan materi evaluasi untuk mengukur ketercapaian siswa dalam pembelajaran, menyediakan umpan balik (feedback) dan memberikan skor langsung untuk memutuskan apakah siswa telah menguasai kemampuan yang dinyatakan dalam tujuan pembelajaran.

\section{Analisa Aspek Efektifitas Produk}

Berkaitan dengan effektifitas bahan ajar modul dalam pembelajaran, terjadi pergeseran ke arah pendekatan pembelajaran yang lebih berpusat 
pada siswa, menjadikan siswa dibebaskan dari hambatan waktu dan ruang, serta didorong untuk berinteraksi dengan materi dengan cara yang tidak pernah didukung secara memadai dengan metode pembelajaran konvensional. Pergeseran paradigma pendidikan yang menuntut perubahan dari "berpusat pada guru" (teacher centred) ke "berpusat pada siswa" (student centred) membawa konsekuensi bahwa guru bukan satu-satunya sumber belajar dari siswa.

Aspek Efektitifitas praktek Modul Instalasi Motor Listrik Menggunakan Trainer Motor DC Berbasis ATMega 16, dapat dilihat berdasarkan hasil post test. Siswa yang Melaksanakan praktik Modul Instalasi Motor Listrik Menggunakan Trainer Motor DC Berbasis ATMega 16, memiliki rerata (mean) skornya : 7,94. Sedangkan rerata skor postest pada siswa yang tidak praktek Modul Instalasi Motor Listrik Menggunakan Trainer Motor DC Berbasis ATMega 16, skornya adalah: 6,16 lebih rendah dari rerata (mean) post test siswa yang praktek Modul Instalasi Motor Listrik Menggunakan Trainer Motor DC Berbasis ATMega 16, Dengan dukungan data yang terdistribusi normal terlihat adanya perbedaan dari nilai rerata praktek Modul Instalasi Motor Listrik Menggunakan Trainer Motor DC Berbasis ATMega 16, dengan yang tidak praktek Modul Instalasi Motor Listrik Menggunakan Trainer Motor DC Berbasis ATMega 16.

\section{Analisa Aspek Daya Tarik Produk}

Hasil interview siswa kelas XI L 2 di ruang praktek SMK Sinar Husni 2 TR Labuhan Deli, di tunjukan melalui data seperti yang tampak pada tabel di bawah ini :

Tabel 1.Tabel Analisis Daya Tarik Produk

\begin{tabular}{|c|c|c|c|}
\hline No & Pertanyaan & Ya & Tidak \\
\hline 1. & $\begin{array}{l}\text { Apakah menurut anda modul } \\
\text { ini menarik, dan mudah untuk } \\
\text { dipelajari? }\end{array}$ & 28 & 4 \\
\hline 2. & $\begin{array}{l}\text { Apakah modul ini mudah } \\
\text { dipahami, serta mudah untuk } \\
\text { belajar mandiri? }\end{array}$ & 26 & 6 \\
\hline 3. & $\begin{array}{l}\text { Apakah modul ini mudah untuk } \\
\text { digunakan dan mudah } \\
\text { dimengerti? }\end{array}$ & 27 & 5 \\
\hline
\end{tabular}

Hasil rekapitulasi wawancara pada penilaian aspek daya Tarik dan kemudahan penggunaan bahan ajarModul Instalasi Motor Listrik Menggunakan Trainer Motor DC Berbasis ATMega 16, untuk siswa menunjukkan bahwa $87 \%$ siswa menyatakan produk ini sangat menarik dan mudah digunakan.

"there are three things to remember about education, The first one is the motivation, the second one is motivation, the third one is motivation". Menyiratkan betapa pentingnya peranan motivasi bagi siswa sebagai energi untuk terlibat dalam tugas belajar. Karena itu, aspek daya tarik disyaratkan sebagai salah satu kriteria utama pembelajaran karena effektifitas dalam memotivasi siswa untuk tetap terlibat dan pada tugas belajar.

Beberapa hasil penelitian yang mendukung pendekatan yang berpusat pada siswa (student centred) bahkan meletakkan kriteria ini diatas dua kriteria lainnya, yaitu efektif dan efisien. Demikian pula hasil evaluasi disain grafis memberikan penilaian sangat baik pada tampilan gambar, warna, ukuran huruf, tata letak (lay out) Modul. Di SMK Sinar Husni 2 TR Labuhan Deli hal ini memberikan situasi baru dan tidak biasa dialami siswa. Hal ini diharapkan dapat menarik perhatian dan memberikan tantangan kepada siswa untuk menyelesaikan tugas belajarnya. Meskipun demikian hal-hal yang baru memungkinkan terjadinya konflik kognitif (disequilibrium) "ketika seorang anak mengalami peristiwa baru, terjadi ketidakseimbangan sampai dia mampu mengasimilasikan dan mengakomodasikan informasi baru tersebut untuk mencapai "equilibrium”.

Untuk Piaget, equilibrium adalah faktor utama dalam menjelaskan mengapa beberapa anak maju lebih cepat dalam pengembangan kecerdasan logis dari pada orang lain. Penelitian menemukan bahwa meski pemanfaatan bahan ajar Modul Instalasi Motor Listrik Menggunakan Trainer Motor DC Berbasis ATMega 16, untuk siswa SMK Sinar Husni 2 TR labuhan Deli, merupakan hal yang baru bagi siswa, namun kemudahan belajar yang dinyatakan oleh $84 \%$ siswa, menunjukan siswa dapat beradaptasi secara cepat dan mampu mengasimilasi dan mengakomodasi bahan ajar modul dalam pembelajaran. Meski terdapat beberapa kendala siswa yang lebih menggunakan bahan ajar Modul Instalasi Motor Listrik Menggunakan Trainer Motor DC Berbasis ATMega 16, dalam praktek, Hal tersebut mungkin disebabkan " $a$ mementary state of disequilibrium" yaitu konflik kognitif sementara yang dapat diatasi siswa dengan melakukan trial and error, yaitu dengan mencobacoba dan mengulang sampai siswa tersebut dapat beradaptasi dan mampu mengasimilasi dan mengakomodasi bahan ajar tersebut dalam praktek.

\section{Kesesuaian Produk yang dihasilkan dengan Tujuan Pengembangan}

Produk yang dihasilkan dalam suatu penelitian pengembangan harus benar-benar sesuai dengan tujuan penelitian pengembangan itu sendiri. Tujuan penelitian pengembangan ini sebagaimana disebutkan pada bagian pendahuluan adalah 
menghasilkan produk bahan ajar modul Modul Instalasi Motor Listrik Menggunakan Trainer Motor DC Berbasis ATMega 16, yang kemudian dilihat kemanfaatannya dalam pembelajaran praktek yang sebenarnya.

Dengan sajian materi berbentuk Trainer yang dilengkapi dengan tes formatif. Produk bahan ajar modul Modul Instalasi Motor Listrik Menggunakan Trainer Motor DC Berbasis ATMega 16, ini dapat berfungsi sebagai pelengkap (komplemen) dalam pembelajaran praktek Instalasi Motor Listrik. Dengan demikian produk yang dihasilkan penelitian ini sesuai dengan tujuan pengembangan dengan keunggulan dan keterbatasannya.

\section{Keunggulan Produk Hasil Pengembangan}

Produk berupa bahan ajar Modul Instalasi Motor Listrik Menggunakan Trainer Motor DC Berbasis ATMega 16, yang digunakan untuk siswa/instruktur, hasil pengembangan ini memiliki beberapa keunggulan yaitu : 1) Isi program sesuai dengan kurikulum Instalasi motor listrik ( IML ) yang dibutuhkan siswa. 2) program ini dilengkapi gambar-gambar komponen sesuai produk yang digunakan dalam Modul Instalasi Motor Listrik 3) bahan ajar Modul Instalasi Motor Listrik Menggunakan Trainer Motor DC Berbasis ATMega 16, memungkinkan siswa untuk pengulangan (retrieval), sehingga informasi yang diberikan mudah dicerna dan dapat bertahan lama untuk memori siswa.

\section{Keterbatasan Penelitian}

Bagaimanapun, selain memiliki keunggulan, sebuah produk juga memiliki keterbatasan, beberapa keterbatasan dari modul menggunakan Trainer ini adalah : 1) Jumlah Trainer masih satu unit, sehingga siswa belum bisa secara maksimal menggunakan trainer. 2). Kondisi phisik Trainer perlu penyempurnaan, agar daya tahan terhadap benturan menjadi lebih baik. 3). Tidak dikembangkan keseluruh SMK dan hanya memiliki sample random untuk penelitian.

Keterbatasan penelitian dan pengembangan bahan ajar Modul Instalasi Motor Listrik Menggunakan Trainer Motor DC Berbasis ATMega 16, terletak pada : 1) Proses revisi yang terusmenerus sesuai dengan perkembangan IPTEK dibidang system kendali elektronik (non plc), 2) populasi kurang memadai, hanya bersifat sebagian populasi siswa SMK Sinar Husni yang dapat mengimplementasikan hasil penelitian ini.

\section{SiMPULAN DAN SARAN}

\section{Kesimpulan}

Berdasarkan data hasil penelitian yang telah diuraikan, maka dapat disimpulkan penelitian terlaksana sesuai dengan tujuan penelitian yaitu:

a. Peneliti telah menghasilkan sebuah produk berupa Modul dan Trainer menggunakan motor DC berbasis Atmega 16 pada pembelajaran Instalasi Motor Listrik yang dapat mendukung kebutuhan belajar siswa untuk mengatasi kesulitan belajar serta meningkatkan hasil belajar, Modul dan Trainer yang dihasilkan sesuai dengan tuntutan kurikulum 2013.

b. Pengembangan Modul dan Trainer menggunakan motor DC berbasis Atmega 16 pada pembelajaran Instalasi Motor Listriktelah mengikuti prosedur penelitian dan pengembangan (research and development) berdasarkan skema the major step in the $R \& D$ cycle Borg \& Gall. Peneliti hanya merujuk hingga ke prosedur ke sembilan, dengan tingkat kevalidan dari validator ahli media rata-rata skor 0,94 dengan kriteria Valid, dan ahli materi ratarata skor 0,904 dengan kriteria Valid.

c. Hasil pengembangan untuk Praktikalitas Modul dan Trainer menggunakan motor DC berbasis Atmega 16 pada pembelajaran Instalasi Motor Listrik dilihat dari kategori siswa dan guru, dikategorikan Praktis. Uji Praktikalitas siswa sebagai pengguna modul menunjukkan nilai ratarata 4,37 dengan kriteria Praktis, sedangkan guru memiliki rata-rata 4,50 dengan kriteria Praktis.

d. Keefektifan Modul dan Trainer menggunakan motor DC berbasis Atmega 16 pada pembelajaran Instalasi Motor Listrik, yang didapat dari hasil pengembangan dapat dikategorikan Efektif . Efektifitas ditunjukkan melalui analisis data terhadap siswa kelas XI L 3 sebagai kelas kontrol yang tidak menggunakan modul pembelajaran dan kelas XI L 3 sebagai kelas eksperimen yang menggunakan modul dan trainer pembelajaran. Data pendukung menunjukkan pada saat pretest Nilai rerata kelas kontrol 5,31 sedangkan kelas eksperimen 5,46, selanjutnya nilai post test untuk kelas kontrol 6,15dan kelas ekperimen 7,56, nilai posttes menunjukkan hasil yang berbeda, Data hasil belajar tersebut menyimpulkan bahwa penggunaan modul dan trainer menggunakan motor DC berbasis Atmega 16, Efektif dan dapat meningkatkan hasil belajar siswa.

\section{Saran}

a. Bagi Guru Mata Pelajaran Praktek Instalasi Motor Listrik, pengembangan dan pengadaan 
model pembelajaran yang menggunakan media Modul dan Trainer perlu terus dilakukan, karena dengan penggunaan media pembelajaran yang lebih konkrit atau dengan pengamatan langsung, maka pesan (informasi) pada proses pembelajaran yang disampaikan guru kepada siswa akan tersampaikan dengan baik. Akan tetapi sebaliknya jika penggunaan media pembelajaran semakin abstrak maka pesan (informasi) akan sulit diterima siswa, dengan kata lain siswa menghadapi kesulitan dalam memahami dan mencerna materi yang disampaikan oleh guru.

b. Bagi Guru Mata Pelajaran Praktek Instalasi Motor Listrik, hendaknya aktif mengikuti perkembangan teknologi pembelajaran melalui berbagai media dan kreatif dalam memecahkan persoalan kesulitan belajar siswa, karena melalui keaktifan mengikuti perkembangan teknologi pembelajaran dapat diketahui model dan stategi pembelajaran yang kemungkinan cocok untuk diterapkan dan melalui kreatifitas sesuatu yang baru dapat dihasilkan.

c. Bagi Guru Mata Pelajaran Praktek Instalasi Motor Listrik, hendaknya membuat jadwal pelatihan secara berkala, untuk memperbanyak pelatihan guna meningkatkan kompetensi guru. sehingga akan semakin meningkatkan motivasi siswa belajar dan rasa percaya diri guru saat mengajar.

d. Kepala Sekolah sebagai kreator dan motivator hendaknya secara terus menerus memotivasi siswa dan guru agar mau belajar dan bersamasama menjadikan suasana perubahan dalam dunia pendidikan untukmenghasilkan tamatan yang berkualitas dan bardaya guna.

\section{DAFTAR PUSTAKA}

[1] D. P. Mahesi Agni Zaus, Rizky Ema Wulansari, Syaiful Islami, "Perancangan Media Pembelajaran Listrik Statis dan Dinamis Berbasis Android," vol. 1, no. 1, pp. 1-7, 2018.

[2] A. Yulastri, H. Hidayat, Ganefri, S. Islami, and F. Edya, "Developing an Entrepreneurship Module by Using Product-Based Learning Approach in Vocational Education," Int. J. Environ. Sci. Educ., vol. 12, no. 5, pp. 1097-1109, 2017.

[3] D. Pernanda, M. A. Zaus, R. E. Wulansari, and S. Islami, "Effectiveness of instructional media based on interactive cd learning on basic network at vocational high school : improving student cognitive ability Effectiveness of instructional media based on interactive cd learning on basic network at vocational hig," Int. Conf. Educ. Soc. Sci. Technol., no. February, 2018.

[4] Sardiman A.M, Interaksi dan Motivasi BelajarMengajar. Jakarta: PT Raja Grafindo Persada, 2006.

[5] G. Priowijanto, Materi Simulasi Digital. Jakarta: Seamolec. Jakarta: Seamolec, 2013.

[6] S. Arikunto, Metodologi Penelitian Suatu Pendekatan Proposal. Jakarta: PT. Rineka Cipta., 2002.

\section{Biodata Penulis}

Purwanto, lahir di Batu Sangkar, 30 November 1963. Sarjana Pendidikan di Jurusan Teknik Elektro FPTK IKIP PADANG 1987. Tahun 2016 memperoleh gelar Magister Pendidikan di jurusan Teknologi Pendidikan Program Pascasarjana UNP dengan bidang konsentrasi Pendidikan Kejuruan Teknik Elektro. Guru SMK Negeri 4 Medan dan Guru serta Pembina di YP Sinar Husni sampai sekarang. 